\title{
A social work study to measure the impact of socio-economical factors of tourism industry
}

\author{
Mohsen Pourkhosravani $^{\mathrm{a}^{*}}$ and Mohammad Reza Iravani ${ }^{\mathrm{b}}$
}

${ }^{a} \mathrm{PhD}$ student in Geomorphology, Department of Geography, University of Isfahan, Isfahan, Iran

${ }^{b}$ Department of Social Work, Islamic Azad University of Khomeinishahr, Khomeinishahr Branch, Daneshjou Blvd, Iran

\begin{tabular}{|c|c|}
\hline ARTICLEINFO & A B S T R A C T \\
\hline $\begin{array}{l}\text { Article history: } \\
\text { Received July 10, } 2011 \\
\text { Received in Revised form } \\
\text { October, 12, } 2011 \\
\text { Accepted 15December } 2011 \\
\text { Available online } \\
\text { 24 December } 2011 \\
\text { Keywords: } \\
\text { Maymad } \\
\text { Tourism } \\
\text { Socio-economical factors } \\
\text { Low carbon industry } \\
\text { Middle East }\end{array}$ & $\begin{array}{l}\text { Tourism plays an important role on development of economy especially in developing } \\
\text { countries. The proposed study of this paper studies the impact of tourism on developing } \\
\text { economic factors such as average income, real estate prices, etc. We have distributed } 110 \\
\text { questionnaires among different people who are involved in various positions in the regions and } \\
\text { analyzed the data. The survey is looking for the impact of tourism industry in terms of } \\
\text { economical and social factors for one of the oldest villages in Iran named Maymand. The } \\
\text { results indicate that there is a strong positive relationship, 0.873, between developing economy } \\
\text { and tourism. In other word, developing tourism industry will help create more jobs, increase } \\
\text { land prices, increase people's income and flourish environment. There is also a positive } \\
\text { correlation, } 0.854 \text {, between social development and tourism industry. This means we could } \\
\text { expect a better health care system as well as medical treatment facilities, which helps prevent } \\
\text { immigration to big cities. }\end{array}$ \\
\hline
\end{tabular}

\section{Introduction}

Tourism plays an important role on developing economy especially for countries located in Middle East. These countries are important for many reasons such as the existence of historical monuments, diversity in weather conditions, etc. Chen (2010) studied the impact of economy and tourism growth on the performance of tourist hotels in Taiwan. They used occupancy rate (OPR), return on assets (ROA), return on equity (ROE), stock return, and the overall financial performance measured by a comprehensive score to measure the impact of tourism on this sector. Their empirical findings suggested some valuable information for government tourism policymakers and tourist hotel owners and managers.

There are other advantages of developing tourism in such countries such as lowering green gas effects. In fact, there is a growing interest in getting rid of industries, which are mostly blamed for

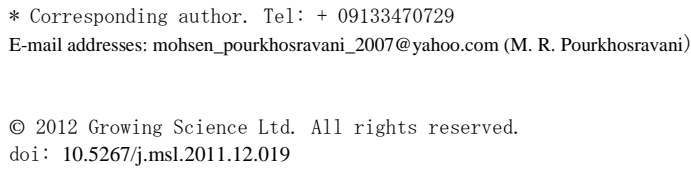


green effects. Can and Hongbing (2011) proposed a model for developing low-carbon tourism in the context of leisure economy. They presented the necessary theory and practice status of low carbon tourism, built the developing framework of low-carbon tourism in the context of leisure economy, and explained the implementation of their model for developing low carbon tourism in China. Tang et al. (2011) investigated the fundamental conception of low-carbon tourism and studied the literature on low-carbon tourism within and outside China. They discussed the benefits of tourist administration, tourism enterprises, tourism attractions and tourists to reach higher quality of tourism experience and greater economic, social and environmental advantages with energy saving and emission reduction.

Schubert et al. (2011) studied the impacts of international tourism demand on economic growth of some small economies relying on tourism. They studied the effects on economic growth of a small tourism-driven economy created by an increase in the growth rate of international tourism demand and presented a framework and empirical evidence. Their results indicated that an increase in the growth of tourism demand helps to transitional dynamics with gradually improving economic growth and improving terms of trade. They also used an empirical study based on an econometric technique on a region of Antigua and Barbuda from 1970 to 2008.

Liu and Wall (2006) tried to expand perspectives on human resources development in tourism planning. Thomas et al. (2011) presented a comprehensive literature review on the role of small business units on tourism industry. One of the important issues for attracting more international tourist into a region is the existence of different risks.

Shareef and Hoti (2005) studied small island tourism economies and country risk ratings. They provided a comparison of monthly country risk ratings compiled by some important factors from 1984 to 2001 and analyzed the relationship between country risk and economic growth for them. They reported a positive economic growth rate and risk ratings in only 13 of the 24 cases, which was a surprising result as the country risk literature asserts that increases in risk ratings are noticeably influenced by higher economic growth rates, and vice versa.

One of the most important issues affecting tourism industry in Middle East countries is the existence of religious restrictions. In fact, women are not allowed traveling to Islamic countries without their partners and they are not able stay in communities without scurf. In these countries, the tourism industry must be accompanied with other ethical issues. There are many studies for investigating ethical issues on tourism industry (Yang \& Wall, 2009). The proposed study of this paper studies the impact of tourism on developing economic factors such as average income, real estate prices, etc.

The other change in the world is the recent increase on energy prices, which could impact the cost of transportation. As a result, we may expect a hike on tourism industry. Becken and Lennox (2012) investigated the impact of oil price on tourism industry in New Zealand and reported a reduction in real gross national disposable income of $1.7 \%$ for a doubling of oil price and a $9 \%$ reduction in the real value of tourism exports. Note that the greatest reduction in demand is measured for tourists from the United Kingdom.

The organization of this paper first presents details of our research in section 2. Section 3 explains details of our finding and concluding remarks are given in the last section to summarize the contribution of the paper.

\section{Survey framework}

The proposed study of this paper is implemented for a region of Iran called Meymand located in province of Kerman, Iran. This village has a 3000 years history and the people who presently live there have kept their old traditional culture. The village of Meymand is considered as the seventh 
cultural historical cities in the world and it has been awarded a special prize from different international organizations. Fig. 1 shows a simple perspective of the village.

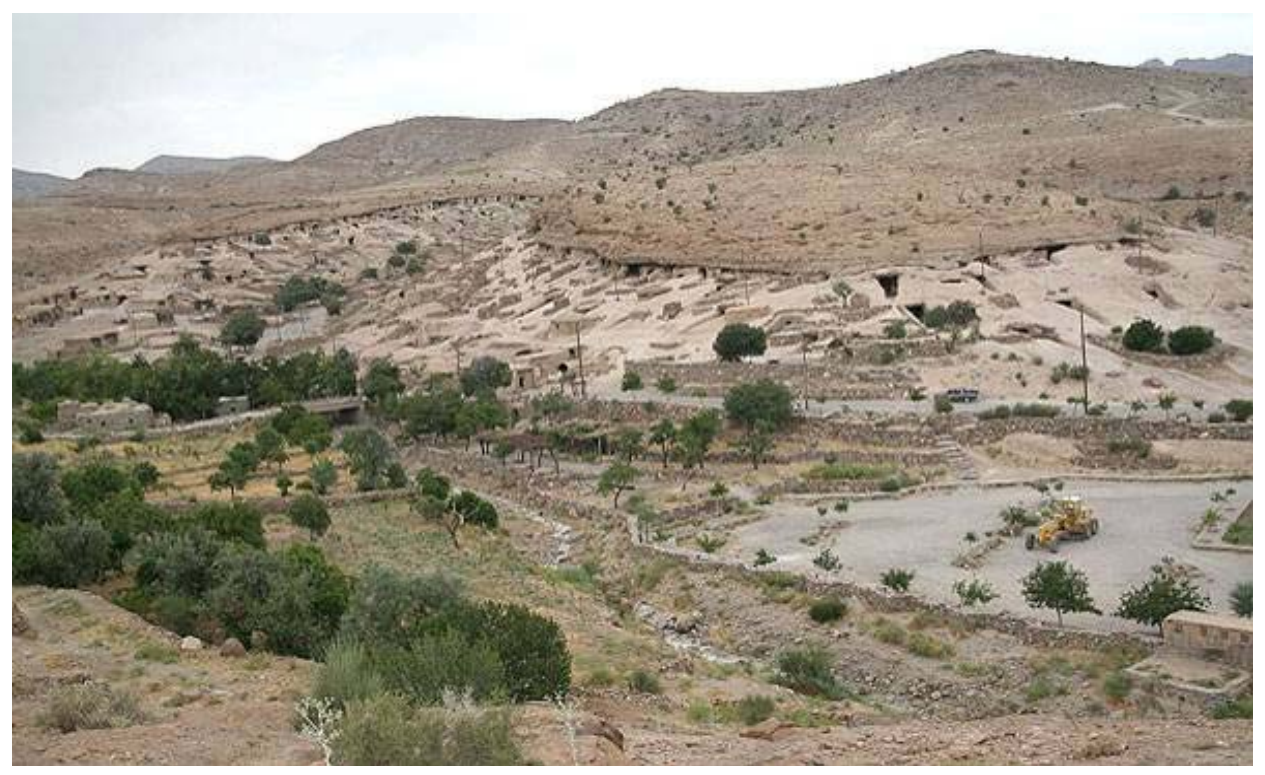

Fig. 1. A simple perspective of the village of Matmand

We have distributed 110 questionnaires among different people who are involved in various positions in the regions and analyzed the data. All questions are designed based on Likert scale (Likert, 1932) and Cronbach Alpha (Cronbach,1951) was calculated as 0.8393, which validates the results of our survey.Table 1 shows details of the personal characteristics of the people who participated in our survey in terms of theor gender and age characteristics.

\section{Table 1}

Personal characteristics of the participants

\begin{tabular}{lccccc}
\hline & \multicolumn{2}{c}{ Age } & \multicolumn{2}{c}{ Gender } \\
\hline & $15-30$ & $30-50$ & $>50$ & Female & Male \\
Freq. & 35 & 30 & 45 & 60 & 50 \\
$\%$ & 31.8 & 27.2 & 40.9 & 54.5 & 45.5 \\
\hline
\end{tabular}

The results of Table 1 shows that the people who participated in our survey were middle age and they represent good experienced residents to provide responses for the questions of our survey.

\section{Table 2}

Ocupation and educational bachgrounds of the participants

\begin{tabular}{lcccccccc}
\hline & & Occupation & \multicolumn{4}{c}{ Years of educations } \\
\hline & Agriculture & Worker & Farmer & Other & $<5$ & $6-8$ & $9-12$ & $>12$ \\
Freq. & 32 & 46 & 13 & 19 & 40 & 35 & 30 & 5 \\
$\%$ & 29.1 & 41.8 & 11.8 & 17.3 & 36.4 & 31.8 & 27.3 & 4.5 \\
\hline
\end{tabular}

As we can observe from the results of Table 1, a noticible percentage of the participants are mostly workers who were either involved in agricultural industry or worked as farmer or regular worker and they were poorly educated. 
In our survey, we have divided the questions in two groups of economical and social factors. The responces measured the impact of each question based on Likert scales of Great, Good, Average and Low. Table 3 demonstrates details of our questions along with their responses on our survey.

Table 3

Survey responses for the questions

\begin{tabular}{|c|c|c|c|c|}
\hline & Title & Scale & Freq. & $\%$ \\
\hline \multirow{16}{*}{$\begin{array}{l}\text { Economical } \\
\text { perspectives }\end{array}$} & \multirow[t]{4}{*}{ The role of toursim in developing craft industries } & Great & 23 & 20.9 \\
\hline & & Good & 47 & 42.7 \\
\hline & & Average & 23 & 20.9 \\
\hline & & Low & 17 & 15.5 \\
\hline & \multirow[t]{4}{*}{ The role of toursim on job creation } & Great & 61 & 55.5 \\
\hline & & Good & 34 & 30.9 \\
\hline & & Average & 12 & 10.9 \\
\hline & & Low & 3 & 2.7 \\
\hline & \multirow{4}{*}{ The role of toursim on increasing income } & Great & 60 & 54.5 \\
\hline & & Good & 24 & 21.8 \\
\hline & & Average & 24 & 21.8 \\
\hline & & Low & 2 & 1.8 \\
\hline & \multirow{4}{*}{ The role of toursim on increasing real estat prices } & Great & 13 & 11.8 \\
\hline & & Good & 32 & 29.1 \\
\hline & & Average & 33 & 30.0 \\
\hline & & Low & 32 & 29.1 \\
\hline \multirow{12}{*}{ Social perspe } & $\begin{array}{l}\text { The role of toursim on increasing village general } \\
\text { equipments }\end{array}$ & Great & 48 & 43.6 \\
\hline & & Good & 36 & 32.7 \\
\hline & & Average & 17 & 15.5 \\
\hline & & Low & 9 & 8.2 \\
\hline & $\begin{array}{l}\text { The role of toursim on increasing health care } \\
\text { systems }\end{array}$ & Great & 45 & 40.9 \\
\hline & & Good & 36 & 32.7 \\
\hline & & Average & 19 & 17.3 \\
\hline & & Low & 10 & 9.1 \\
\hline & $\begin{array}{l}\text { The role of toursim on reducing immigration from } \\
\text { the village }\end{array}$ & Great & 18 & 16.4 \\
\hline & & Good & 45 & 40.9 \\
\hline & & Average & 23 & 20.9 \\
\hline & & Low & 24 & 21.8 \\
\hline
\end{tabular}

\section{Results}

We have analyzed the questions using SPSS software package, we have measured Pearson correlation ratios for two groups of questions, and the results are summarized in Table 4. 
Table 4

The results Pearson correlation ratio

\begin{tabular}{llllll}
\hline Independent variable & Dependent variable & Frequency & Impact & P-value & Alpha \\
\hline Developing tourism & Economical factors & 110 & 0.873 & 0.000 & 0.7188 \\
& Social factors & 110 & 0.854 & 0.000 & 0.8234 \\
\hline
\end{tabular}

The results of our survey show that tourism industry has positive impact on economical and social factors in the case study. The correlation ratios for economical and social factors are 0.873 and 0.854 , respectively.

\subsection{Economical factors}

The results of our analysis for economical factors indicate a strong relationship between tourism industry and other economical factors. In other words, tourism industry in this region will develop craft industry, help create tourist related jobs, increase people's annual income and boost real estate industry. In terms of national advantage, an increase on people's personal income could help country's economy since many foreign tourists travel to country and other associated sectors are influenced, positively.

\subsection{Social factors}

In this survey, over 40 percents of the people who participated in our survey believed that the tourism industry could help health case and general equipment needed. This is an overwhelming feedback, which could encourage domestic government to invest more in this industry and try to help industry grow faster.

One of the most important issues in developing countries is to help people stay in their hometown or villages and prefer not to immigrate to bigger cities. Tourism is believed to be one of the well-known industries, which could help small societies grow and stabilize. Our survey also indicates that this industry has had positive impact on preventing people of immigrating to big cities. However, there were people who believed that tourism could not prevent their relative of migrating from the village.

During the past few years, Iran was one of 10 countries blamed for green gas effects and global warming. The country could reduce the impact by developing tourism industry helping the country reduce the green gas effect. The authors believe Iran has more historical monument and civilization than many other countries such as France. When 70 million people annually travel to France, we could expect the same potential in Iran too.

\section{Conclusion}

We have presented an empirical study to measure the impact of tourism industry on developing economic factors such as average income, real estate prices, etc. The survey has distributed 110 questionnaires among different people who were involved in various positions in the regions and analyzed the gathered data. The survey was looking for the impact of tourism industry in terms of economical and social factors for one of the oldest villages in Iran named Maymand. The results indicated that there is strong positive relationship, 0.873, between developing economy and tourism. In other word, developing tourism industry will help create more jobs, increase land prices, increase people's income and flourish environment. There was also a positive correlation, 0.854, between social development and tourism industry. This means we could expect a better health care system as well as medical treatment facilities, which helps prevent immigration to big cities. 


\section{Acknowledgment}

The authors would like to thank Islamic Azad University for their financial support on this project. The author also grateful for constructive comments received from the anonymous referees on earlier version of this working paper.

\section{References}

Becken, S., \& Lennox, J. (2012). Implications of a long-term increase in oil prices for tourism. Tourism Management, 33(1), 133-142.

Can, H., \& Hongbing, D. (2011). The model of developing low-carbon tourism in the context of leisure economy. Energy Procedia, 5, 1974-1978.

Chen, M.H. (2010).The economy, tourism growth and corporate performance in the Taiwanese hotel industry. Tourism Management, 31(5), 665-675.

Cronbach, L. J. (1951). Coefficient alpha and the internal structure of tests. Psychometrika, 16(3), 297-334.

Likert, R. (1932). A Technique for the Measurement of Attitudes. Archives of Psychology, 140, 1-55.

Liu, A., \& Wall, G. (2006). Planning tourism employment: a developing country perspective. Tourism Management, 27(1), 159-170.

Schubert, S.F., Brida, J.G., \& Risso, W. A. (2011). The impacts of international tourism demand on economic growth of small economies dependent on tourism. Tourism Management, 32(2), 377385.

Shareef, R. \& Hoti, S. (2005). Small island tourism economies and country risk ratings. Mathematics and Computers in Simulation, 68(5-6), 553-566.

Tang, Z., Shi, C.B., \& Liu, Z. (2011). Sustainable development of tourism industry in China under the low-carbon economy. Energy Procedia, 5, 1303-1307.

Thomas, R., Shaw, G., \& Page, S. J. (2011). Understanding small firms in tourism: A perspective on research trends and challenges. Tourism Management, 32(5), 963-976.

Yang, L., \& Wall, G. (2009). Ethnic tourism: A framework and an application. Tourism Management, 30(4), 559-570. 